\title{
Pengembangan E-Modul Berbasis Discovery Learning pada Materi Larutan Elektrolit dan Non Elektrolit Kelas X SMA/MA
}

\section{Development of E-Module Based on Discovery Learning on Topic of Electrolyte and Non-Electrolyte Solutions For Grade X SMA/MA}

\author{
V A Arianti ${ }^{1 *}$ and R Zainul ${ }^{1}$ \\ ${ }^{1}$ Pendidikan Kimia, Universitas Negeri Padang, Jl. Prof. Dr. Hamka, Air Tawar Barat, \\ Padang Utara, Sumatera Barat, Indonesia 25171 \\ *viscaalisia96@gmail.com
}

\section{ARTICLE INFO}

Received 17 October 2019

Revised 31 January 2020

Published 18 May 2020

\begin{abstract}
This research aims to develop teaching materials in the form of e-modules that are valid and practical. The type of research used is research and development $(R \& D)$. The development model used is the 4-D model which includes 4 stages, namely the define, design, develop and disseminate. Research carried out until the development stage, namely the validity and practicality test. The instruments used were validity and practicality sheets. The e-module was validated by 6 validators, while the practicality test was conducted by 3 chemistry teachers and 30 students XI MIA 6 of SMAN 5 Padang. The results of the validity and practicality analysis showed a validity value of 0.840 with a very high category. The practicality value by students is 0.920 and the teacher is 0.841 with a very high category. Thus, e-module based on discovery learning on electrolyte and non-electrolyte solution materials in class X SMA/MA is valid and practical.
\end{abstract}

\section{KEYWORDS}

E-Module, Discovery Learning, Electrolyte and Non-Electrolyte, Research and Development, 4-D Models

\begin{abstract}
ABSTRAK
Penelitian ini dilakukan untuk mengembangkan bahan ajar dalam bentuk e-modul yang valid dan praktis. Jenis penelitian yang digunakan adalah penelitian dan pengembangan (R\&D). Model pengembangan yang digunakan yaitu model 4-D meliputi 4 tahap, yaitu pendefinisian, perancangan, pengembangan dan penyebaran. Penelitian dilakukan sampai tahap pengembangan, yaitu uji validitas dan praktikalitas. Instrumen yang digunakan yaitu lembar validitas dan praktikalitas. E-modul divalidasi oleh 6 validator, sedangkan uji praktikalitas oleh 3 guru kimia dan 30 siswa XI MIA 6 SMAN 5 Padang. Hasil analisis validitas dan praktikalitas didapatkan nilai validitas yaitu 0,840 dengan kategori sangat tinggi. Nilai praktikalitas oleh siswa yaitu 0,920 dan guru 0,841 dengan kategori sangat tinggi. Sehingga, e-modul berbasis discovery learning pada materi larutan elektrolit dan non elektrolit kelas X SMA/MA valid dan praktis.
\end{abstract}

\section{KATA KUNCI}

E-Modul, Discovery Learning, Elektrolit dan Non Elektrolit, Penelitian dan Pengembangan, Model 4-D 


\section{PENDAHULUAN}

Ilmu kimia merupakan ilmu pasti dan dipelajari pada tingkat sekolah menengah atas. Ilmu kimia mempelajari tentang susunan, komposisi, sifat-sifat dan perubahan materi sekaligus perubahan energi yang menyertainya ${ }^{[1]}$. Tujuan dari ilmu kimia ini yaitu menerapkan konsep-konsep kimia agar dapat menyelesaikan masalah dalam kehidupan seharihari dan teknologi ${ }^{[2]}$.

Larutan elektrolit dan non elektrolit adalah materi pembelajaran kimia di kelas $\mathrm{X}$ semester dua yang dianggap sulit oleh siswa. Materi dari larutan elektrolit dan non elektrolit memiliki dimensi faktual, konseptual serta prosedural. Materi ini memiliki 3 aspek yang harus dipelajari, yaitu makroskopik, submikroskopik dan simbolik. Materi ini membutuhkan siswa untuk memahami, menghafal, menghitung dan menganalisis konsep. Pemahaman konsep merupakan hal yang harus dikuasai oleh siswa untuk tercapainya tujuan pembelajaran. Berdasarkan Permendikbud No. 65 tahun 2013 tentang standar pendidikan dasar dan menengah, sasaran dari pembelajaran mencakup ranah kognitif, afektif, dan psikomotor melalui pendekatan saintifik dengan menerapkan model pembelajaran sesuai tuntutan kompetensi dasar dan karakteristik siswa.

Berdasarkan hasil wawancara dan angket yang di isi siswa di SMAN 5 Padang, SMA Pembangunan Laboratorium UNP dan SMAN 1 Kubung diperoleh hasil (1) materi larutan elektrolit dan non elektrolit masih kurang dipahami oleh siswa, (2) bahan ajar masih berupa buku cetak dan lembar kerja siswa, (3) siswa masih kurang memahami materi dengan bahan ajar dari sekolah. Berdasarkan wawancara dengan guru diperoleh hasil guru belum menggunakan langkah-langkah discovery learning dalam bahan ajar.

Seiring berkembangnya teknologi, proses pembelajaran dituntut untuk dapat memanfaatkan sarana teknologi yang ada. Salah satunya menggunakan komputer. Pada umumnya, komputer hanya digunakan dalam mengetik tugas, soal dan word processing. Salah satu hasil perkembangan teknologi pada zaman sekarang adalah bahan ajar yang berbentuk elektronik contohnya e-modul. Keunggulan e-modul dibandingkan modul cetak adalah sifatnya yang interaktif dan memungkinkan untuk memuat gambar, animasi, video, audio dan movie serta dilengkapi dengan tes/kuis formatif $^{[3]}$. E-modul disusun secara sistematis dan disajikan dalam bentuk elektronik.

Berdasarkan penelitian Farenta, dkk (2019) pengembangan E-module yang valid dan praktis membantu siswa untuk memahami materi ${ }^{[4]}$. Hal ini juga dilakukan Zulkarnain (2015) menghasilkan e-modul yang valid dan praktis sehingga dapat digunakan dalam pembelajaran ${ }^{[5]}$. E-modul pada materi sistem peredaran darah yang dihasilkan juga valid dan praktis untuk pembelajaran oleh siswa SMP kelas VIII ${ }^{[6]}$. Begitu juga penelitian yang dilakukan oleh Oktavia, dkk (2018) menyatakan guru tertarik untuk mengembangkan dan menggunakan e-modul dalam proses belajar mengajar ${ }^{[7]}$. Penelitian selanjutnya dilakukan oleh Chairi, dkk (2019) yaitu pengembangan LKS dengan pendidikan saintifik berbasis discovery learning memiliki tingkat validitas dan praktikalitas yang tinggi ${ }^{[8]}$. Penelitian Santika, dkk (2016) penerapan model discovery learning dapat meningkatkan kemampuan luwes peserta didik ${ }^{[9]}$. Bahan ajar yang dikembangkan memiliki beberapa kelemahan yaitu peserta didik cenderung bersifat informatif, gambar yang disajikan sederhana, berisikan soal latihanlatihan saja ${ }^{[10]}$.

Dari permasalahan itu dilakukan pengembangan bahan ajar dalam bentuk e-modul berbasis discovery learning dengan judul "Pengembangan E-Modul berbasis Discovery Learning pada Materi Larutan Elektrolit dan Non Elektrolit pada Kelas X SMA/MA".

\section{METODE}

Penelitian yang dilakukan berjenis penelitian dan pengembangan (R\&D). Model pengembangannya yaitu model 4-D (four $D$ models) terdiri dari 4 tahap, yaitu tahap pendefinisian, tahap perancangan, tahap pengembangan, dan tahap penyebaran $^{[11]}$. Penelitian dilakukan sampai tahap develop, yaitu uji validitas dan praktikalitas. Karena keterbatasan waktu dan biaya, tahap penyebaran tidak dilakukan. Subjek penelitian ini adalah 3 orang dosen kimia FMIPA UNP, 3 orang guru kimia dan 30 orang siswa kelas XI MIA 6 di SMAN 5 Padang.

Pertama tahap define yaitu tahap mendefinisikan. Tahap ini dilakukan bertujuan untuk menetapkan dan mendefinisikan syarat yang dilakukan dalam proses pembelajaran ${ }^{[12]}$. Tahap mendefinisikan terdiri dari lima langkah yang dimulai dari: (a) tahap analisis ujung-depan (front end analysis) yaitu tahap-tahap yang melaksanakan wawancara dengan guru kimia yang bertujuan untuk mengetahui suatu masalah yang dihadapi dalam proses belajar mengajar oleh guru dan siswa; (b) tahap analisis siswa, caranya dengan menyebarkan angket yang bertujuan untuk mengetahui karakter dari siswa tersebut; (c) tahap analisis tugas bertujuan untuk perumusan indikator yang sesuai dengan KD pada materi pembelajaran, Kompetensi Dasar (KD) 3.8 dan 4.8 dianalisis terlebih dahulu; (d) tahap analisis konsep, yang dilakukan pada tahap ini adalah analisis konsep dari materi KD 3.8; (e) tahap perumusan tujuan pembelajaran, tahap ini bertujuan untuk mencapai tujuan pembelajaran yang harus dicapai siswa.

Tahap design, tahap ini terdiri dari 3 tahap yaitu tahap memilih media, memilih format dan merancang awal desain ${ }^{[12]}$. Tahap ini dilakukan untuk mendapatkan rancangan dari e-modul berbasis discovery learning. Tahap pertama yaitu tahap pemilihan media, hal ini berguna untuk memilih media yang baik dan relevan, sehingga dapat digunakan dalam pembelajaran. Media yang dipilih 
berguna untuk menyesuaikan antara konsep yang dianalisis dan tugas yang dianalisis, dan karakteristik pengguna; Selanjutnya memilih format e-modul, pada tahap ini produk di desain mulai dari isi, strategi, pendekatan, model pembelajaran. Memilih format yang menarik dan memudahkan siswa akan membuat siswa senang dalam pembelajarannya sehingga mudah untuk memahami konsep; tahap terakhir adalah merancang awal e-modul[12].

Tahap develop, tahap ini akan menghasilkan perangkat pembelajaran yang sudah direvisi sesuai dengan saran dan masukan oleh validator ${ }^{[12]}$. Penelitian dilakukan untuk menghasilkan e-modul yang berbasis discovery learning pada materi larutan elektrolit dan non elektrolit kelas X SMA/MA. E-modul yang dihasilkan adalah e-modul yang sudah valid dan praktis sehingga dapat digunakan dalam pembelajaran oleh siswa dan guru. Tahap yang dilakukan meliputi: (a) menguji validitas e-modul, tujuan pengujian ini untuk memperoleh dan mengungkap tingkat valid atau tidaknya e-modul yang dikembangkan; (b) selanjutnya dilakukan revisi untuk memperbaiki e-modul yang dianggap tidak tepat oleh validator sebelum e-modul diujikan: (c) tahap uji coba dilakukan untuk mengetahui praktis atau tidake-modul yang telah dikembangkan. Karena keterbatasan waktu dan biaya, penelitian ini hanya dilakukan hingga tahap develop.

Instrumen yang digunakan berupa angket validasi dan praktikalitas. Lembar angket validasi diberikan kepada dosen kimia Fakultas Matematika dan IPA UNP dan guru kimia SMA Negeri 5 Padang. Lembar angket berfungsi untuk menilai validitas e-modul berbasis discovery learning yang dikembangkan. Sedangkan lembar praktikalitas ditujukan kepada siswa dan guru kimia, dari lembar praktikalitas ini kita mengetahui e-modul yang dikembangkan praktis atau tidak.

Data yang didapat dari angket diolah menggunakan rumus kappa cohen.

Tabel 1. Kategori Keputusan berdasarkan Momen Kappa $^{[13]}$.

\begin{tabular}{c|c} 
Interval & Kategori \\
\hline $0,81-1,00$ & Sangat tinggi \\
\hline $0,61-0,80$ & Tinggi \\
\hline $0,41-0,60$ & Sedang \\
\hline $0,21-0,40$ & Rendah \\
\hline $0,01-0,20$ & Sangat rendah \\
\hline$<0,00$ & Tidak valid
\end{tabular}

\section{HASIL DAN DISKUSI}

\subsection{Tahap Pendefinisian (Define)}

\subsubsection{Menganalisis ujung depan.}

Ini dilakukan untuk mengetahui masalah yang dihadapi guru dan siswa dalam proses pembelajaran ${ }^{[14]}$.Sehingga hal ini bisa dijadikan dasar dalam pengembangan e-modul berbasis discovery learning. Tahap analisis ujung depan dilakukan dengan mewawancarai guru kimia. Hasil dari wawancara dengan guru kimia SMA Negeri 5 Padang, SMA Negeri 1 Kubung dan SMA Laboratorium Universitas Negeri Padang didapatkan hasil sebagai berikut: (1) masih kurangnya pemahaman siswa terhadap materi yaitu larutan elektrolit dan non elektrolit; (2) bahan ajar yang digunakan masih berupa LKS, buku cetak dan modul; (3) belum diaplikasikannya tahap-tahap model pembelajaran discovery learning pada bahan ajar. Discovery learning adalah sebuah model pembelajaran yang digunakan agar siswa aktif sehingga dapat menemukan dan menyelidiki sendiri, hasil yang diperoleh pun akan teringat lebih lama dan siswa tidak mudah melupakannya ${ }^{[14]}$. Penelitian sebelumnya juga menggunakan model pembelajaran yang sama yaitu discovery learning, tapi bahan ajar yang dikembangkan dalam berupa lembar kerja siswa ${ }^{[15]}$. Keunggulan e-modul adalah 1) tingkat motivasi siswa lebih tinggi; 2) sifat statis pada modul bisa dikurangi, karena memuat unsur visual menggunakan video tutorial[ ${ }^{[16]}$.

\subsubsection{Menganalisis siswa.}

Karakter siswa antara lain karakteristik belajar siswa dalam proses pembelajaran misalnya seperti keseriusan dalam proses pembelajaran, kemampuan menerima pelajaran, motivasi belajar, keaktifan dalam pembelajaran dan lain-lain dapat diketahui setelah dilakukan analisis siswa ${ }^{[12]}$. Jika kita mengetahui karakteristik siswa maka itu akan mempermudah dalam pembuatan e-modul. Tahap ini dilakukan dengan cara pengisian angket oleh siswa SMAN 5 Padang, SMAN 1 Kubung dan SMA Laboratorium UNP. Berdasarkan hasil yang diperoleh menyatakan bahwa kemampuan akademik dan motivasi mereka dalam belajar tergolong cukup. Menurut teori piaget tentang perkembangan anak yaitu anak yang berumur 12-18 tahun sudah berada pada tahap operasional formal. Anak sudah dapat berfikir secara abstrak, logis dan sistematik untuk memecahkan masalah melalui kegiatan eksperimentasi seperti menarik kesimpulan, menafsirkan dan mengemukakan hipotesis pada umur 12-18 tahun ${ }^{[17]}$. Dari data angket yang didapat menyatakan bahwa siswa sudah dapat mengoperasikan komputer sendiri.

\subsubsection{Menganalisis tugas.}

Menganalisis tugas dilakukan agar konsep pokok yang harus dikuasai siswa dalam pembelajaran dapat teridentifikasi. Menganalisis tugas dilakukan dengan menganalisis kompetensi dasar dari materi ajar yang hendak dicapai siswa ${ }^{[12]}$. Tahap ini dilakukan berdasarkan analisis KD kurikulum 2013 revisi 2018. Materi dari larutan elektrolit dan non elektrolit termuat pada Kompetensi Dasar 3.8 dan 4.8. KD 3.8 yaitu menganalisis sifat larutan berdasarkan daya hantar listriknya; 4.8 membedakan daya hantar listrik berbagai larutan melalui perancangan dan pelaksanaan percobaan. Berdasarkan KD 
tersebut dapat dirumuskan indikator pencapaian kompetensi yaitu 1) Menganalisis larutan elektrolit dan non elektrolit, 2) Menganalisis penyebab larutan elektrolit dapat menghantarkan arus listrik, 3) Menelaah daya hantar listrik senyawa ion, kovalen polar dan kovalen non polar, 4) Merancang alat uji daya hantar listrik beberapa larutan, 5) Melaksanakan percobaan membedakan daya hantar listrik beberapa larutan.

\subsubsection{Menganalisis konsep.}

Konsep dianalisis untuk mendapatkan konsep pokok yang harus diajarkan pada saat pembelajaran. Konsep disusun dalam bentuk hierarki dan konsepkonsepnya terperinci ${ }^{[12]}$. Berdasarkan analisis konsep maka akan didapatkan atribut-atribut konsep pada materi. Konsep utama pada materi ini adalah larutan, zat terionisasi, zat tidak terionisasi, elektrolit, non elektrolit, elektrolit kuat, elektrolit lemah, setelah konsep dianalisis maka akan didapatkan peta konsep.

\subsubsection{Menganalisis tujuan pembelajaran.}

Menganalisis tujuan pembelajaran ini adalah hasil analisis tugas dan analisis konsep yang dirumuskan dalam bentuk tujuan pembelajaran ${ }^{[12]}$. Setelah atribut-atribut konsep didapatkan, maka kita akan mudah menentukan tujuan pembelajaran dari materi. Dari indikator pencapaian kompetensi tersebut maka didapatkan tujuan pembelajaran dari materi. Tujuan pembelajaran dari materi ini adalah Melalui model Discovery learning dengan strategi belajar mandiri dengan berbasis komputer peserta didik diharapkan mampu mengidentifikasi larutan, zat terlarut dan pelarut, menganalisis larutan elektrolit dan non elektrolit, menentukan derajat ionisasi/disosiasi dari larutan, menganalisis penyebab larutan elektrolit dapat menghantarkan arus listrik, menganalisis daya hantar listrik senyawa ion dan kovalen polar, merancang alat uji daya hantar listrik larutan dan melaksanakan percobaan membedakan daya hantar listrik beberapa larutan.

\subsection{Tahap Merancang}

Tahap ini dilakukan untuk mendesain e-modul berbasis discovery learning. Tahapan ini terdiri dari 3 tahap yaitu memilih media, memilih format, merancang awal. Pemilihan media (media selection) dapat menyampaikan materi berdasarkan tujuan pembelajaran yang dibuat. Media dipilih dan disesuaikan dengan analisis konsep dan analisis tugas untuk membantu siswa mencapai kompetensi dasar yang diharapkan oleh kurikulum ${ }^{[11]}$. Media yang dipilih berupa modul elektronik atau disebut juga e-modul. Tahap selanjutnya adalah pemilihan format, pada pemilihan format yang dilakukan yaitu menganalisis kompetensi inti (KI), kompetensi dasar (KD), menganalisisindikatorpencapaiankompetensi, dan menganalisis tujuan pembelajaran ${ }^{[11]}$. Tahap ini dilakukan untuk mendesain media yang dimulai dari strategi pembelajaran, pendekatan, model dalam yang digunakan saat pembelajaran ${ }^{[12]}$. E-modul ini menggunakan strategi pembelajaran berbasis komputer, pendekatan saintifik, dan model pembelajaran discovery learning. Pada kurikulum 2013 digunakan pendekatan saintifik, pendekatan saintifik menerapkan langkah-langkah metode ilmiah $^{[18]}$. Penggunaan model discovery learning akan mengubah cara belajar yang pasif menjadi belajar yang aktif dengan cara siswa menemukan informasi sendiri[ $\left.{ }^{[18]}\right)$. Selanjutnya yaitu rancangan awal, Berdasarkan kemendikbud (2017) komponenkomponen yang harus terdapat dalam e-modul adalah: cover, petunjuk belajar baik untuk guru maupun siswa, peta konsep, lembar kegiatan, lembar kerja siswa, lembaran tes siswa, kunci jawaban dan glosarium $^{[10]}$. Lembaran kegiatan siswa disusun berdasarkan tahap-tahap model pembelajaran discovery learning ${ }^{[19]}$.

Pembuatan awal desain e-modul menggunakan aplikasi Microsoft Publisher 2010, Adobe Flash CS6, Wondershare Filmora dan menggunakan Kvisoft Flipbook Maker.

\subsection{Tahap Pengembangan}

\subsubsection{Uji validasi.}

Validitas merupakan penilaian terhadap rancangan suatu produk. Produk itu dikatakan valid jika instrumennya dapat mengukur sesuatu yang hendakdiukur ${ }^{[18]}$.Uji inibertujuan untuk memberikan penilaian terhadap rancangan produk. Aspek yang dinilai pada tahap pengujian ini yaitu komponen isinya, komponen kebahasaannya, komponen penyajiannya dan komponen kegrafikaannya ${ }^{[20]}$. Pada penelitian sebelumnya yaitu e-modul asam basa berbasis discovery learning untuk kelas X SMA/ MA dihasilkan e-modul yang valid dan praktis ${ }^{[21]}$. E-modul ini divalidasi oleh 3 orang dosen kimia FMIPA UNP dan 3 orang guru kimia SMA Negeri 5 Padang. Validnya suatu produk dinilai minimal oleh tiga orang ahli ${ }^{[19]}$. Hasil dari uji validitas e-modul dapat dilihat pada Gambar 1.

\section{Hasil Uji Validitas E-Modul Larutan Elektrolit dan Non Elektrolit oleh Validator}

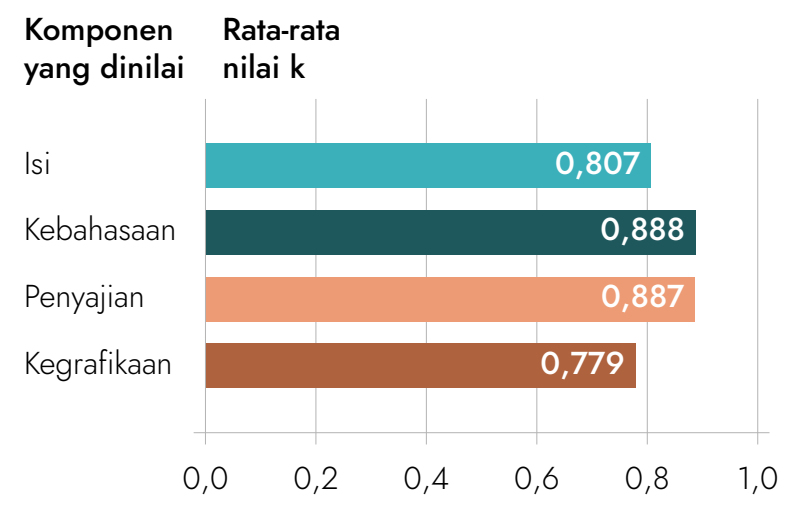

Gambar 1. Hasil analisis data validitas oleh validator.

Komponen isi e-modul didapatkan nilai ratarata sebesar 0,807 dengan kategori tinggi. Dapat disimpulkan e-modul yang dikembangkan sesuai 


\section{Hasil Uji Praktikalitas E-Modul Larutan Elektrolit dan Non Elektrolit oleh Guru dan Siswa}

Kemudahan Penggunaan

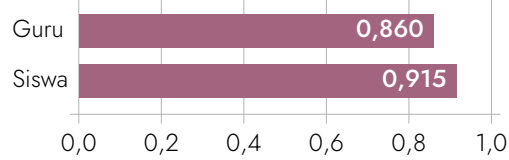

Efisiensi Waktu Pembelajaran

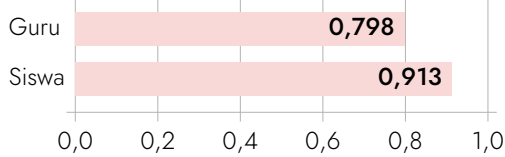

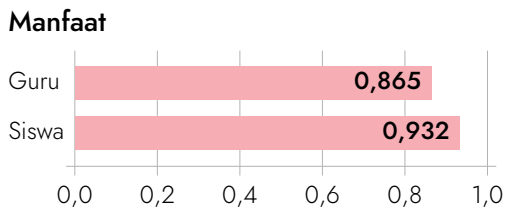

Gambar 2. Hasil analisis data praktikalitas oleh guru dan siswa.

dengan tuntutan kompetensi pada kurikulum 2013 revisi 2018.

Pada komponen kebahasaan didapatkan nilai sebesar 0,888 dengan kategori sangat tinggi. Dapat disimpulkan bahasa yang digunakan sudah sesuai dengan Ejaan Bahasa Indonesia. Bahasa yang komunikatif akan mempermudah siswa untuk mengerti dan memahami konsep ${ }^{[22]}$.

Pada komponen penyajian e-modul mendapatkan nilai sebesar 0,887 termasuk kategori sangat tinggi. Penyajian yang menarik akan membuat motivasi siswa dalam belajar lebih tinggi. Ini membuktikan e-modul yang dikembangkan sesuai dengan indikator dan tujuan pembelajaran yang dirumuskan. E-modul yang dikembangkan memiliki tahap-tahap discovery learning ${ }^{[17]}$.

Pada e-modul terdapat gambar, animasi, audio, video, movie dan pertanyaan-pertanyaan yang terkait dengan materi sehingga membuat siswa tertarik untuk belajar ${ }^{[3]}$. Materi yang menuntut siswa untuk memahami 3 aspek yaitu makroskopik, submikroskopik dan simbolik ini tidak hanya bisa dipahami oleh kata-kata dan gambar yang biasa saja, tetapi jika dibantu dengan animasi interaktif maka bahan ajar akan memiliki kriteria yang baik mulai dari aspek materinya, bahasa Indonesia, dan medianya $^{[10]}$.

Pada komponen kegrafikaan diperoleh nilai sebesar 0,779 dan termasuk kategori tinggi. Dapat disimpulkan ukuran huruf, tata letak, layout dan desain tampilannya jelas dan membuat siswa tertarik. Hal tersebut menyatakan bahwa e-modul berbasis discovery learning yang dikembangkan memiliki layout, tata letak, video, gambar, desain tampilan dan ukuran huruf yang jelas. Animasi membuat daya ingat siswa lebih tahan lama karena bersifat lebih nyata. Sehingga siswa akan memperoleh hasil belajar yang lebih bagus dengan memenuhi kriteria ketuntasan minimal[23].

Hasil validasi yang diberikan oleh 6 validator akan dilakukan revisi. Hal ini dikarenakan kurang tepatnya beberapa hal yang terdapat pada e-modul. Revisi bertujuan agar e-modul yang dikembangkan lebih baik dan bagus.

\subsubsection{Revisi .}

Pada tahap ini hal yang kurang tepat akan diperbaiki sesuai saran dan masukan dari validator. Sehingga e-modul yang dikembangkan lebih sempurna. Revisi dilakukan sebelum produk diujicobakan. Jika e-modul sudah dikatakan valid oleh validator maka produk boleh diuji coba. Saran dan masukan dari validator yaitu: 1) menambah kalimat perintah pada link untuk menjawab; 2) pada video tambahkan perintah untuk menulis hasil pengamatan; 3) senyawa pada animasi derajat ionisasi larutan elektrolit lemah diganti.

\subsubsection{Uji coba.}

Tingkat kepraktisan dari produk yang dikembangkan akan dapat diketahui dengan cara uji coba produk. Hasil praktikalitas dilihat pada Gambar 2.

Pada kemudahan penggunaan e-modul didapatkan nilai dari siswa sebesar 0,915 dengan kriteria sangat tinggi, sedangkan pada guru didapatkan nilai sebesar 0.86 dengan kriteria sangat tinggi. Pada aspek efisiensi waktu pembelajaran, didapatkan nilai dari siswa sebesar 0,913 dengan kriteria sangat tinggi, sedangkan dari guru sebesar 0,798 dengan kriteria tinggi. Pada aspek manfaat, e-modul yang mendapatkan nilai dari siswa sebesar 0,932 dengan kriteria sangat tinggi, sedangkan dari guru sebesar 0,865 dengan kriteria sangat tinggi.

\section{SIMPULAN}

Penelitian yang dilakukan bertujuan untuk mengetahui valid dan praktisnya e-modul berbasis discovery learning pada materi larutan elektrolit dan non elektrolit yang dikembangkan, sehingga e-modul dapat digunakan dalam belajar mengajar dan memudahkan siswa dalam memahami konsep larutan elektrolit dan non elektrolit. Berdasarkan penelitian yang dilakukan didapatkan hasil bahwa e-modul berbasis discovery learning yang valid dan praktis.

\section{REFERENSI}

1. Brady JE. Chemistry Matter and Its Changes. New York: John Wiley \& Sons, Inc.; 2009.

2. Kementerian Pendidikan dan Kebudayaan. Permendikbud Nomor 65 Tahun 2013 tentang Standar Proses Pendidikan Dasar dan Menengah. Jakarta: Kemendikbud; 2013.

3. Suarsana IM, Mahayukti GAA. Pengembangan E-Modul Berorientasi Pemecahan Masalah Untuk Meningkatkan Keterampilan Berpikir Kritis Mahasiswa. J Nas Pendidik Tek Inform 2013;2(2):193-200.

4. Farenta AS, Sulton $S$, Setyosari P.

Pengembangan E-module Berbasis Problem Based Learning Mata Pelajaran Kimia untuk Siswa Kelas X SMA Negeri 8 Malang. I Pendidik 2016;1(6):1159-68. 
5. Zulkarnain A, Kadaritna N, Tania L. Pengembangan E-modul Teori Atom Mekanika Kuantum Berbasis WEB dengan Pendekatan Saintifik. I Pendidik dan Pembelajaran Kim 2015;4(1):222-35.

6. Prasetyaningrum A. Pengembangan Electronic-module (E-Module) berbasis Kasus Materi Sistem Peredaran Darah Manusia Untuk Mengoptimalkan Hasil Belajar Siswa di SMA. 2015;

7. Zainul R, Oktavia B, Guspatni, Putra A. Pengenalan dan Pengembangan E-Modul Bagi Guru-Guru Anggota MGMP Kimia dan Biologi Kota Padang Panjang. INA-Rxiv 2018;

8. Chairi I, Ellizar, Zainul R. Pengembangan LKS dengan Pendekatan Saintifik Berbasis Discovery Learning Pada Materi Hukum Dasar Kimia untuk Pembelajaran Kelas X SMA/MA. INA-Rxiv 2016;

9. Santika AD, Betta R, Efkar T. Penerapan Discovery Learning dalam Meningkatkan Kemampuan Berpikir Luwes Materi Elektrolit dan Non Elektrolit. J Pendidik dan Pembelajaran Kim 2016;5(3):143-55.

10. Wiyoko T, Rahardjo DT. Pengembangan Media Pembelajaran Fisika Modul Elektronik Animasi Interaktif untuk Kelas XI SMA Ditinjau dari Motivasi Belajar Siswa. I Pendidik Fis 2014;2(2):11.

11. Trianto. Model Pembelajaran Terpadu: Konsep, Strategi dan Implementasinya dalam Kurikulum Tingkat Satuan Pendidikan (KTSP). Jakarta: Bumi Aksara; 2012.

12. Trianto. Pengantar Penelitian Pendidikan Bagi Pengembangan Profesi Pendidikan dan Tenaga Kependidikan. Jakarta: Kencana; 2011.

13. Sarah Boslaugh PAW, Boslaugh S dan PAW, A WP. Statistics in A Nutshell, a desktop quick reference. Beijing, Cambridge, Farmham, Koln, Sebastopol, Taipei, Tokyo, Cambridge, Famham, Köln, Sebastopol, Taipei,Tokyo: O'reilly; 2008.

14. Hosnan. Pendekatan Saintifik dan Kontekstual dalam Pembelajaran Abad 21. Bogor: Ghalia Indonesia; 2014.

15. Lovita Y. Pengembangan Lembar Kegiatan Siswa (LKS) Berbasis Discovery Learning pada Materi Larutan Elektrolit dan Non Elektrolit untuk Pembelajaran Kimia Kelas X SMA/MA. 2015;

16. Kemendikbud. Panduan Praktis Penyusunan E-Modul Pembelajaran. Jakarta: Direktorat Pembinaan SMA; 2017.

17. Omrod J. Psikologi Pendidikan. 6th ed. Jakarta: Erlangga; 2014.

18. Kementerian Pendidikan dan Kebudayaan. Permendikbud Nomor 59 Tahun 2014 tentang Kurikulum 2013 Sekolah Menengah Atas/ Madrasah Aliyah. Jakarta: Kemendikbud; 2014.

19. Depdiknas. Panduan Pengembangan Bahan Ajar. Jakarta: Departemen Pendidikan Nasional Direktorat Jenderal Manajemen
Pendidikan Dasar dan Menengah Direktorat Pembinaan Sekolah Menengah Atas; 2008.

20. Sugiyono. Metode Penelitian Pendidikan. Bandung: Alfabeta; 2013.

21. Setiadi T, Zainul R. Pengembangan E-Modul Asam Basa Berbasis Discovery Learning untuk Kelas XI SMA/MA. Edukimia 2019;1(1):21-7.

22. Lasmiyati. Pengembangan Modul Pembelajaran untuk Meningkatkan Pemahaman Konsep dan Minat SMP. I Pendidik Mat 2014;9(2):161-74.

23. Ruwaida M. Penggunaan Animasi dengan Macromedia Flash untuk Meningkatkan Daya Ingat terhadap Matematika pada Materi Geometri di Kelas X SMA Negeri 3 Banda Aceh. Ilm Didakt 2012;XII(2):199-215. 